\title{
THE ENGLISH SYSTEM OF REAL PROPERTY TAXATION
}

\section{Frank B. Murdoch, Jr. $\dagger$}

Since colonial times the various local governmental units in the United States have been financed in the most part by a levy upon real property. The amount of tax levied has been determined by a certain fixed percentage of the capital value or fair market value of a given parcel of real estate, while the percentage or tax rate has been determined by the financial needs of the local unit of government. In this respect our system is similar to that of England.

This system worked fairly well in the first century and a half of our Republic, for during that time real estate was constantly appreciating in value as a result of the free development of our immense natural resources, the tremendous growth in population of a nation that encouraged immigration, and the rapid rise of industrialism. The continuing presence of these factors was assumed, so that market value was computed upon a potential increase; that is, the future was discounted. Eventually then the market value of real property came to bear no reasonable relation to its income value. The taxing authorities, however, had only been doing their sworn duties in raising assessed valuations correspondingly with the selling price of real estate. Needless to say, the local governments expanded their activities upon the basis of increased tax returns, and more tragically, they floated large bond issues based upon the assumed high values existent in the Twenties. The subsequent collapse of the real estate market found the local governments with large bonded indebtedness which had to be serviced, and expanded functions which had to be continued. The inevitable result was that taxes based upon false values exceeded the income of the property and finally effected confiscation. With this situation existing for the past five years or more, there has arisen a feeling that real property taxation should be based upon the income value of real estate. It therefore seems pertinent to consider the English system of local taxation, in which the tax on real estate is calculated on the income value, rather than on the capital value, and is levied not on the owner but on the occupier of the property.

One must turn to the Middle Ages and the days of feudalism to understand the modern English system of rating. There must be brought to mind the fact that life in England during that period centered about the manor. The manor was the unit of English social and industrial life. Human secular relationships were regulated by the Lord of the Manor through the

† A. B., 1926, LL. B., 1929, University of Pennsylvania; member of the Philadelphia Bar; member of the Committee on Taxation, Pennsylvania Bar Association. This article is the result of a field survey conducted in England, in I934. 
Court Baron. The Lord of the Manor held his land subject to certain military services which he rendered to the King. His vassals or tenants lived in the village with the right to use various strips of farm land, in return for which they performed military service and worked upon the Baron's land so many days per year, doing the necessary plowing, sowing and reaping. In such a primitive community there was no need for local taxation.

The quarreling of French and English Kings, however, made it imperative for the latter to secure military service for longer periods than was due them under the terms of the feudal grants by which the lords baron held their lands. The result was that money payments which would secure mercenary soldiers were made by the lords baron in substitution for the military services of their tenants or vassals and themselves. The lords baron in turn required money payments from their tenants. These developments coincided with the growth of an export demand for English wool; so that there was a "money crop" from which lords and vassals could secure cash to pay in lieu of personal military services.

While these changes were evolving, England was swept in I 348 by the Black Death, which halved the population of England in a year. Although the Statutes of Labourers ${ }^{1}$ were passed immediately to regulate the price of labor, it was difficult to secure labor at any price. The result was that the lords baron reasserted their disused rights to the personal services of their tenants. This created unrest among the masses, which broke forth into armed revolt when a poll tax was levied in $\mathbf{1} 379$. While this Peasants' Revolt was put down, its twin causes, the inability to adjust labor disputes and the difficulty of relieving the poor, remained. The passage of time only aggravated conditions. By the opening of the sixteenth century the breakdown of the feudal manorial system was complete; the Black Death had ultimately resulted in the abolition of serfdom, despite the quashing of the Peasants' Revolt; the end of the Wars of the Roses in 1485 had set free a large number of soldiers; and the situation in general was one in which large groups of penniless and homeless people were drifting around England to the endangerment of its social structure.

Conditions became so intolerable that Parliament was forced to act, and in $\mathrm{r} 530$ it empowered justices of the peace to license the helpless to beg within certain areas. ${ }^{2}$ Where begging was done beyond the licensed confines the beggars were to be punished. Penalties were also imposed on all ablebodied beggars. But it soon became apparent that this law was not curing or even retarding the growth of pauperism and unemployment.

Accordingly, a new law was enacted in $1535 .^{3}$ This enactment provided that the authorities of the parish, the ecclesiastical counterpart of the now

I. 23 EDW. III (1349).

2. 22 HEN. VIII, C. I2 (I530).

3. 27 HeN. VIII, c. 25 (I535). 
defunct manor, were to care for the poor arriving in their parish with alms raised by the clergy. The alms were to be used to set up work-houses in which "valiant beggars" and "sturdy vagabonds" were expected to "get their own living with the continual labour of their own hands." This statute was very important, because it contained the six main principles which underlie the poor laws or laws of local taxation in England, namely: (I) that the duty to help support the poor is enforceable by the state; (2) that the parish is the governmental unit to enforce this duty; (3) that the helpless poor are to be relieved at the cost of the community in which they were settled; (4) that children of persons who cannot maintain themselves must be taught a trade and set to work; ( 5 ) that the able-bodied vagrant or beggar is to be suppressed by the machinery of the criminal law; (6) that the able-bodied poor must have work provided for them and be compelled to do it.

The choice of the parish as the unit for poor relief was both a natural and good one, for the parish had performed many secular duties even in feudal times in connection with the management of real estate and the personal property given to it by its members. ${ }^{4}$ But despite the fact that the clergy followed the letter of the act and did "exhort, move, stir and provoke people to be liberal and bountiful and to extend their good and charitable alms", the alms collected unfortunately fell short of the amount required to carry out the duties placed upon the parish by Parliament.

An attempt was made in $x 552$ to remedy this situation by another statute. ${ }^{5}$ This Act provided that the collectors of the parish should "gently ask and demand of every man and woman what they of their charity will be contented to give weekly toward the relief of the poor", and they are further to report if any there were who "able to further this charitable work do obstinately or frowardly refuse." Provision was made that recalcitrant members of the community were to be summoned before the bishop, who was to "take order for the reformation thereof." This Act was a step forward in that the alms were to be a stated amount paid at a stated time, and the parish could rely upon a regular weekly amount.

It developed that reformation by the bishop was not enough to produce sufficient alms, and so the end of a decade saw the enactment of another statute. $^{B}$ By this Act the bishop was further empowered to bind over to the Quarter Sessions of the Peace any person who obstinately refused to give according to his ability. The justices of the Quarter Sessions were to assess or rate such a person in their discretion and upon default of his payment of such assessment or rating to commit him to prison.

In 1572 , the powers of the justices were enlarged. ${ }^{7}$ They were to list the helpless who had been residing in their district for three years, determine 
their place of settlement, estimate the cost of maintaining them, assess the inhabitants and appoint collectors. They were also to appoint an overseer, a new officer, to supervise the work of rogues and vagabonds.

This system continued to function in a fairly satisfactory way until the four years of bad harvests from I 594 to I 597 placed upon it a strain it could not bear. When Parliament met in I597, proposals for the relief of the poor occupied the first consideration of the lawmakers. A series of acts was passed in I597, which were somewhat enlarged and re-enacted as a whole in I6or. ${ }^{8}$ This poor law, commonly known as the Statute of Elizabeth, provided for the establishment of a system of poor rates, which, so far as determination of liability, measure of liability and enforcement of liability for local taxes or "rates" are concerned, continued in substance until the drastic revision of local taxation by the Rating Act of $1925 .{ }^{9}$

The general method of the Statute of Elizabeth, used to finance poor relief, was soon extended for the collection of taxes for other purposes, such as the repair of highways, relief of prisoners, relief of disabled soldiers and sailors, police, water, and in fact all the additional demands made upon local government with the passing of years and the growth of an industrial society. The Statute then was the remote source of liability to the local rates which are now levied. Its provisions directed the overseers of the poor to take orders for setting the poor to work "and also to raise weekly or otherwise (by taxation of every inhabitant, parson, vicar, and other, and of every occupier of lands, houses, tithes impropriate, propriations of tithes, coal mines or saleable underwoods in the said parish, in such competent sum and sums of money as they shall think fit) a convenient stock of flax, hemp, wool, thread, iron and other necessary ware and stuff, to set the poor on work: and also competent sums of money for and towards the necessary relief of the lame, impotent, old, blind, and such other among them, being poor and not able to work, and also for the putting out of such children to be apprentices, to be gathered out of the same parish, according to the ability of the same parish. . . ." The Act further provided that the churchwardens of every parish, together with four, three or two substantial householders according to the size of the parish, should be overseers of the poor with power to fix the rate, and that rate payers should have a right of appeal to Quarter Sessions. This scheme of poor relief made each parish responsible for the maintenance of its own poor; the ecclesiastical unit of the parish became the poor law unit. The poor law official, the overseer, was chosen from or selected by the parish vestry, and the necessary funds were raised by a rate levied upon the householders of the parish.

It is to be observed that the Act of I60I distinguished between inhabitants and occupiers. It provided that occupiers were to be taxed in respect

8. 42 ElIZ. c. 2 (I6OI).

9. I5 \& I6 GEo. V, c. 90 (xg25). 
to the properties which they occupied, and that inhabitants, parsons, vicars and others were to be taxed, but not in respect to any specified subjects. Inhabitants were only taxed upon their stock in trade and not upon all of their personalty. ${ }^{10}$

No directions were given for the guidance of the overseers in assessing the ability of the occupier to pay, except that it was roughly dependent upon the worth of his property. The occupier of valuable property usually had a greater ability to pay than the occupier of a poor property, and he was assessed or rated accordingly. Nor was anything said about collection of the rate. Appeals to Quarter Sessions were provided for, if anyone felt himself aggrieved with any tax or with any act done by the overseers. It thus appears that under the Act of I60I the overseers did their duty as best they could and in such a way as they saw fit.

An important interpretation of the Act was made in 1633 in Sir Anthony Earby's Case, ${ }^{11}$ wherein Sir Anthony Earby and fellow inhabitants of the town of Boston complained "that he having divers tenants there which paid rent unto him, they there did charge his tenants by their assessments, and did charge him also." The judges held "that by the words and meaning of the Statute 43 Eliz. cap. 2, they are to assess the occupiers of the land, and not the lessor who received the rents, the occupier of the land being by law onely to pay the assessment, unless it be specially provided for as to this payment between him and his lessor, and so by this to be discharged of this payment of such assessments." The significance of this decision is difficult to overemphasize, since it conclusively fixed all liability on the occupier.

The statutory amendments to the Act of $160 \mathrm{I}^{12}$ are instructive in that they show the illogical order in which laws relating to local taxation are enacted. They concerned practice, measurement of liability and the determination of liability. The most important amendments were: the Parochial Assessment Act of $1836,{ }^{13}$ which modified the rough "ability to pay" measure of liability of the Act of I6or, and substituted therefor annual rental value; the Poor Rate Exemption Act of $1840,{ }^{14}$ which did away with the partial levy upon personalty; the Union Assessment Committee Act of $1862,{ }^{15}$ which set up an assessment committee of overseers to review the assessments of any single overseer; it provided for the deposit of a draft valuation list by the

I0. Such was the recognized practice, although the case material on the point passes on the question only by implication or dictum. See Regina v. Inhabitants of Barking, 2 Ld. Raym. 1280, I28I (Q. B. I706); Rex v. Guardians of the Poor of Canterbury, 4 Burr. 2290 (K. B. I769); Rex v. Inhabitants of Ringwood, I Cowp. 326 (K. B. I775); Rex v. Hill, 2 Cowp. 6I3 (K. B. I777) ; Rex v. Mast, 6 T. R. I54 (K. B. I795); Rex v. Inhabitants of Darlington, 6 T. R. 468 (K. B. I795) ; Rex v. Inhabitants of Ambleside, I6 East. 380 (K. B. I8I2).

II. 2 Bulst. 354 (K. B. 1633 ).

I2. See Appendix A, infra.

13. 6 \& 7 WirL. IV, c. 96 (1836).

I4. 3 \& 4 VICT. c. 89 ( 1840$)$.

I5. $25 \& 26$ VICT. c. 103 (I862). 
overseer with the committee and a hearing of objections to this list by the committee, and also provided that valuations must be uniform and correct; the Valuation (Metropolis) Act of $1869,{ }^{16}$ which provided for uniformity of assessments in London; the Rating Act of $1874,{ }^{17}$ which abolished the exemption from rating enjoyed up until this time by woodlands, mines other than coal mines, and sporting rights severed from occupation; and the Local Government Act of $1894,{ }^{18}$ which disconnected the association of the ecclesiastical authorities with local government. The powers of the vestry were transferred to the parish council and rural district council.

The result of such haphazard legislation was a complicated system administered unequally by a multitude of governmental bodies with an attendant multiplication of clerical costs. To remedy this situation the Rating and Valuation Act of $1925^{19}$ was enacted.

This Act made fundamental changes in rating practice outside of London, for its main purposes were the promotion of simplicity in making and collecting rates and the establishment of uniformity in fixing the annual rental value. The Act of 1925 abolished overseers of the poor; established one general rate instead of the multitude of rates for particular purposes; reduced the number of rating authorities from I5,400 to I770; abolished the parish as the unit for rating, setting up 344 assessment areas for England and Wales, making the county borough, urban district or rural district the assessment or rating unit; and made a quinquennial valuation compulsory. ${ }^{20}$ The Act became effective on April I, 1927, and has proved very satisfactory in that it has produced a far greater degree of simplicity and uniformity than formerly prevailed. It is the present law by which local taxation is imposed. Surprising as it may seem to a nation that took its system of civil and criminal law from England, the local tax law of England differs altogether from that of the United States in respect to determination of liability, measure of liability and procedure.

In the United States the tax is assessed against the owner of the property and the tax is a lien on the property. In England the tax is levied not against the owner of the property, but against the occupier, be he owner or tenant, and the tax is in nowise a lien against the property. Indeed, essentially the poor rate is not a tax on the land at all, but rather a personal charge in respect to the land. ${ }^{21}$

In England, as in America, various exemptions from liability exist. For instance, scientific societies are exempt from rates, where they occupy land for the transaction of their business and the carrying into effect of their

16. 32 \& 33 VICT. c. 67 ( 1869 ).

I7. $37 \& 38$ VICT. c. 54 (I874).

I8. $56 \& 57$ VICT. c. 73 (I894).

I9. I5 \& I6 GEO. V, c. 90 (I925).

20. See Adrin, Local Taxation (3d ed. I934) 27.

2I. Rowls v. Gells, 2 Cowp. 45I, 452 (K. B. I776). 
purposes. However, for the society to be exempt it must be instituted for purposes of science, literature, or the fine arts exclusively, supported wholly or in part by annual voluntary contributions. Its by-laws must not permit any gift, division or bonus in money to or between its members, and it must secure a certificate that it conforms in all these respects. ${ }^{22}$ In the United States such institutions are exempt under the broad heading of educational institutions.

Churches, chapels and schools that are "exclusively appropriated to public religious worship" are also exempt. It is interesting to note that college and school chapels, such as the chapels at Oxford and Cambridge, are taxable, because they are not exclusively appropriated to public religious worship. Our laws of exemption are, of course, much wider, and exemptions are granted far more freely to religious institutions. Thus, we find that in England Salvation Army Headquarters are taxable, whereas in the United States they are exempt as public charities. So also we find that all English secular schools are taxed, with the exception of ragged schools, which furnished gratuitous education to children of the poorest classes and are now non-existent, and non-provided schools, which are public elementary schools not provided by the local education authority. ${ }^{23}$

Occupiers of agricultural land and agricultural buildings are likewise exempt. However, the English definition of agricultural buildings excludes dwelling houses, and accordingly, the dwelling house used by a farmer is not exempt even though it is used in connection with the agricultural land. ${ }^{24}$ It should be pointed out that the land must actually be "agricultural land"; thus, arable, meadow or pasture ground upon a farm is exempt, but land occupied, together with a house, as a park is not.

As might be expected, property occupied by the Crown or by its servants for Crown purposes is exempt. Also free of tax are national institutions, such as the National Gallery, the British Museum, etc. ${ }^{25}$ However, while the principle of exemption of Crown property is maintained, a contribution equivalent to the tax that otherwise would be paid is now made in respect to most Government property. The property is valued by a treasury officer of the Crown instead of by the ordinary valuation authorities.

Public parks are exempt, as are public roads. Partial exemptions are granted to canals, light railways and burial grounds by provisions that they shall not pay more, after they assume these uses, than was paid before the iand became a canal, a light railway, or a burial ground. There have also been partial exemptions of industrial and freight transport properties under the Apportionment Act of $1928,{ }^{26}$ popularly known as the De-rating Act,

22. The Scientific Societies Act, 6 \& 7 Vict. c. 36 ( 1843 ).

23. The Poor Rate Exemption ACT, 3 \& 4 WILL. IV, c. 30 (I833).

24. LocAl GoVernment Act, I9 Geo. V, c. I7 (I929).

25. Jones v. Mersey Docks, II H. L. Cas. 443 (I865).

26. I8 \& I9 GEo. V, c. 44 (Ig28). 
and certain parts of the Local Government Act of I929. ${ }^{27}$ The combined effect of these acts is that occupiers of industrial and freight transport properties are assessed at only one-fourth of their net annual value; that is, they pay only 25 per cent of the tax that they would normally pay. The amount that the local authorities lose by reason of these de-rating acts is made up by a direct grant by the national government.

Local taxation may be excused entirely on the ground of the poverty of the taxpayer under the Rating and Valuation Act of $1925 .{ }^{28}$

With the exception of the aforesaid exemptions, every occupier of land is liable to pay rates or local taxes. If a property is not occupied it pays no taxes. This brings up the interesting question of what is occupation. Occupation includes possession as its primary element, but it comprises something more as well. Legal possession of itself does not constitute occupation. The owner of a vacant house is in possession and may maintain trespass against anyone who invades it; but as long as he leaves it vacant he is not ratable for it as an occupier. ${ }^{29}$ Property is considered occupied if there is a beneficial occupation of the premises, that is, one of value. Thus, a house at the seashore in which the furniture remains is considered to be beneficially occupied in the winter time although, in point of fact, no one goes there in that season. ${ }^{30}$

In regard to the measurement of liability for local taxes, the English concept differs vastly from the American. We measure liability by means of the capital value or market value of the piece of real estate, while in England liability is measured by means of the income value or annual rental value of the property. The Local Government Act of $1929^{31}$ provides that the measure of liability shall be gross value less certain deductions according to the value of the premises, ${ }^{32}$ which gives the net annual value or the ratable value, as it is sometimes called. The ratable value and net annual value are usually the same, but in some cases there are extra deductions allowed, as where sewers are lacking, and in these cases the ratable value is less than the net annual value. Section 68 provides that "gross value" means the rent at which a hereditament might reasonably be expected to let from year to year, if the tenant undertook to pay all usual tenants' rates and taxes and tithe rent charge, if any, and if the landlord undertook to bear the cost of the repairs and insurance, and the other expenses, if any, necessary to maintain the hereditament in a state to command that rent.

In determining "rental value" for the purpose of measuring liability, the rent actually paid is not conclusive, because it may be higher or lower

27. I9 GEo. V, C. I7 (I929).

28. I 5 \& I6 GEo. V, c. 90 (I925).

29. Regina v. St. Pancras, L. R. 2 Q. B. D. $58 \mathrm{I}$ ( 1877 ).

30. Gage v. Wren, I8 T. L. R. 699 (K. B. r902); London County Council v. Hackney, [1928] 2 K. B. 588.

3I. Ig GEO. V, c. I7 (I929).

32. See Appendix B, infra. 
than the fair rent for the property, but it is evidence of value. ${ }^{33}$ Where the property is one that is never let from year to year, the annual interest on cost is used as a guide to the ascertainment of the annual rental value. ${ }^{34}$ In certain exceptional cases the annual rental value is estimated by recourse to a consideration of the occupier's profits. This has been held proper in the case of a race course, ${ }^{35}$ and of a refreshment stand at a railway station. ${ }^{36}$ A similar basis for measurement is applied to licensed premises or public houses in exceptional cases where it is not possible to compare the premises with others nearby. ${ }^{37}$

A comparison of procedure in the two countries reveals that in the United States the capital value is fixed by an assessor, after which there is an appeal to a county board, usually the county commissioners. From the board's decision there is an appeal in some states to a State Tax Commission, and in others to a court of record. The English procedure is practically the same. The value is placed by a rating authority, a committee assisted by clerks and valuators, from whose decision there is an appeal to the Assessment Committee, which corresponds to our Board of County Commissioners, and from its decision an appeal may be taken to the Court of Quarter Sessions. ${ }^{38}$ In England the valuation is made every five years, whereas in the United States this period is usually from one to three years.

In addition to the regular valuation officers, two bureaus, the County Valuation Committee and the Central Valuation Committee, which disseminate information and appear as interested parties where uniformity is not obtained, have been established. They see to it that there is uniformity in fixing the gross annual value, so that in England there is not the gross inequality in taxation that there is in the United States, where properties within city limits are usually assessed at roo per cent of capital value, while assessments across the city line may be as low as thirty per cent of capital value. Our system has resulted in the continual growth of the suburbs and the complete decay of areas within the city limits, because the tax differential makes it uneconomical to develop the land within the latter area.

There has been some drift in the United States toward the English measure of value in that by statute or decision in a number of states there has been recognized the necessity or propriety of considering the income value of property in fixing its capital or fair market value. ${ }^{39}$ In the opinion of

33. Rex v. Skingle, 7 T. R. 549 (K. B. I798) ; Poplar Assessment Committee v. Roberts, [1922] 2 A. C. 93.

34. Rex v. School Board for London, I7 Q. B. D. 738 (I885).

35. Dodds v. South Shields, [I895] 2 Q. B. 133, 136.

36. Clark v. Aldbury Union, 6 Q. B. D. I39 (1880).

37. Cartwright v. Sculcoaet Union, [I900] A. C. I50.

38. Rating and Valuation ACT, I5 \& I6 Geo. V, c. 90 (I925).

39. E. g., IND. STAT. (Baldwin, I935) § I5685; Iowa Code (I93I) c. 342, § 7I09; Somers v. City of Meriden, I74 At1. I84 (Conn. I934); Schmidt v. Saline County, I22 Neb. 56, 239 N. W. 203 (r93I); State, Hurd v. Cook, 60 N. J. L. 70, 36 Atl. 892 (I887); People ex rel. Szerlip v. Goldfogle, II8 Misc. 8, I92 N. Y. Supp. 2Io (Sup. Ct. I922) ; Northern Pac. Ry. v. Benton County, 87 Wash. 534, I5I Pac. II23 (IgI5). 
the writer, the practice should be extended, for the income value measure of liability is a simple, adequate and uniform measure which is fair to both local governmental unit and taxpayer in a country where real estate values tend to be stable. In fact, such a system of taxation tends to keep real estate values stable because for all purposes people naturally value property upon the basis of its income value rather than upon the basis of potential capital accretions that may or may not take place years in the future.

First hand experience with the valuation made in England in the fall of I934 has convinced the writer of the simplicity, fairness, adequacy, and, above all, flexibility of the English system of raising revenue for local governing units. It may be, indeed, that adoption of some of the English features would supply a solution to our present problem of terminating the confiscation of real property by local taxation.

\section{APPENDIX A.}

\section{Amendments to the Act of r6or}

As might be expected, the earliest modifications of the Act of I60I concerned procedure. The first such was THE JUSTICES JURISDICTION Act, I6 GEO. II, c. I8 (I743). It provided that a justice of the peace could carry out the Act of I60I notwithstanding the fact that he was a ratepayer in the district from which the rate case arose, but further provided that upon an appeal to the Quarter Sessions, a justice could not sit if the case arose from a district in which he was a ratepayer.

Another Act concerning procedure was passed the next year. THE POOR Rate ACT, I7 GEo. II, c. 3 (I744). It provided that the churchwardens and overseers of the poor were to give public notice in church of every rate levied and to furnish the list of ratepayers and their levies to anyone who enquired.

The Poor Relief Act, I7 Geo. II, c. 38 (I744), was passed soon afterwards; it provided that rates levied were to be entered in a rate book, which was to be kept for public perusal. This Act further provided that upon appeals to Quarter Sessions the justices were to give only the relief required by the case before it, and not to quash the entire rate. It further provided that where overseers proceeded by warrants of distress to collect rates which were illegal, they were not to be deemed trespassers $a b$ initio.

The Poor Rate Act, 4I Geo. III, c. 23 (I8or), provided that notices of appeal to quarter sessions must be given to the overseers of the poor and that the grounds of appeal were to be stated in such notices. Where the rate appealed from was that of another, notice must also be given to the persons interested.

The Poor Relief Act, 54 Geo. III, c. I70 (18I4), provided that justices of the peace could, with the consent of parish officers, discharge poor persons from the payment of rates.

The Poor Relief Act, 59 Geo. III, c. I2 (I8I9), provided that vestries could rate owners in certain cases instead of occupiers. This was done where the rent was not less than $£ 6$ nor more than $£ 20$ per annum for any term less than a year.

The Poor Law (Appeals) Act, I Geo. IV, c. 36 (I820), provided for appeals to quarter sessions where a corporate town has not more than two parishes within it. 
The Metropolitan Police Acr, to Geo. IV, c. 44 (I829), provided for assessing and levying a police rate on property within the metropolitan district not subject to poor rate. It stipulated that the sum levied in any year was not to exceed $8 \mathrm{~d}$. the $£$ on the full and fair annual value of such property, and that the assessor was, within forty days after delivery to him of his warrant of appointment, to make an assessment for the place named in the warrant, to be written in a book specifying the names of the occupiers, the full and fair annual value, the amount of police rate charged on such occupiers, the times when the premises were unoccupied, and the annual value thereof to let. Justices nominated persons to levy the police rate, to have the same powers as overseers.

In 1833 the religious faiths other than the established church secured exemption by The Poor Rate Exemption Act, 3 \& 4 Will. IV, c. 30 (i833). This Act exempted from rating persons who occupied churches or places excltsively appropriated to public religious worship.

In I833 the Lighting AND WATCHING ACT, 3 \& 4 WiLl. IV, c. 9o (I833) provided that where the ratepayers voted a certain amount for lighting and watching, it was to be raised by an addition to the poor rate.

The Highway ACt, 5 \& 6 WILL. IV, c. 50 (I835), provided for money to be raised for highway purposes by additions to the poor rate.

The Parochial Assessments Act, 6 \& 7 Will. IV, c. 96 (I836), was extremely important. It was a modification of the "ability to pay" basis of the Statute of Elizabeth, and endeavoured to establish one uniform mode of rating known as net annual value. Net annual value, upon which all rates were to be made, was defined as "the rent at which the same might reasonably be expected to let from year to year free of all tenant's rates and taxes, and from tithe commutation rent charge, if any, and deducting therefrom the probable average annual cost of the repairs, insurance, and other expenses, if any, necessary to maintain them in a state to command such rent."

In I837, The Parish Notices Act, 7 Wirl. IV, I Vict. c. 45 (I837), provided that notices as to the making of rates must be fixed on or near the doors of all churches and chapels instead of announcing the fact during or after divine service.

The Poor Rate Exemption Act, 3 \& 4 Vict. c. 89 (I840), did away with the personalty tax on stock-in-trade which had been levied since $\mathrm{r} 60 \mathrm{I}$ and made poor rates or rating independent of personalty.

The Scientific Societres Act, 6 \& 7 Vict. c. 36 (I843), provided that no person was to be rated where lands and buildings were occupied by scientific societies supported by annual voluntary contributions, where they hold a certificate from the registrar of friendly societies.

The Lands Clauses Consolidation Act, 8 \& 9 Vict. c. $x 8$ (I845), provided that until the completion of works (e.g., railways), promoters were to make good any deficiency in the rates that might occur because of the taking until there was an occupation of the new enterprise.

Justices Protection ACt, II \& I2 VICT. c. 44 (I848), provided that where justices make any mistakes of law, one shall appeal or take a rule upon them in Court of Queen's Bench. Justices were not to be sued for obeying rule.

The Poor Law Amendment Act, it \& i2 Vict. c. Iio (I848), provided that overseers could revalue any part of rateable property in the assessment union where the majority of overseers demanded it.

Distress For RATES ACT, I2 \& I3 VICT. c. I4 (I849), provided that cost of distraint was to be added to the occupier's debt. In default of distress, justices might issue warrant of commitment, one warrant of distress to issue against more than one delinquent ratepayer. 
The Quarter Sessions Act, I2 \& I3 Vict. c. 45 (I849), provided that notice of appeal, stating the grounds of appeal were to be given fourteen days before hearing. No other evidence was to be heard. Costs of appeal were to be directed as Quarter Sessions thought fit. Case might be submitted to arbitration.

County Rates Act, I5 \& I6 Vict. c. 8I (I852), provided that Justices were to make a uniform county rate.

BuRIAL ACT, I8 \& I9 VICT. c. I28 (I855), provided that land for burial was not to be assessed higher than tax at time of acquisition.

Poor Rates Recovery ACt, 25 \& 26 VICT. c. 82 (I862), provided that to recover rates economically the authorities could consolidate proceedings for the recovery of rates.

Union Assessment Committee Act, 25 \& 26 Vict. c. I03 (I862), was an Act to secure uniform and correct valuations. It set up an assessment committee, composed of overseers, to review the assessments of the overseers. It provided for deposit of valuation list and a hearing of objections by the committee. The committee was to have clerks and valuers.

Union Assessment Committee Amendirent Act, 27 \& 28 Vict. c. 39 (I864), provided that no justice should be disqualified for acting on appeals against a poor rate at quarter or special sessions by reason of being rated, or being liable to be rated, in some other parish in the union than that for which the rate appealed against is made.

Poor LAW Amendment Act, 3I \& 32 Vict. c. I22 (I868), provided that accretions from the sea, seashore to low water mark, and rivers to the middle of the stream, were to be annexed to the adjoining parish. Guardians were to appoint a paid valuer to assist the assessment committee.

Sunday and Ragged Schools (Exemption From Rating Act), 32 \& 33 VICT. c. 40 (I869), provided that Sunday schools, and the now non-existent poor or ragged schools, should be exempt.

The Poor Rate Assessment and Collection, 32 \& 33 Vict. c. 4I (I869), provided that lessees for short terms might deduct the poor rate from their rent. Owners might receive a commission of up to 25 per cent where they agree to pay the rates in cases of properties under a certain value.

The Valuation (Metropolis) Act, 32 \& 33 Vict. c. 67 (I869), provided for uniformity of assessment of rateable property in London. It established a quinquennial valuation of all the property in the metropolis and made new property and alterations in value rateable by means of provisional valuation lists, which were collected at the end of the rating year into one list, called the supplemental valuation list. These lists were made by the overseers, who in the metropolis composed the borough council. Objections against the overseers' figures were considered by an assessment committee, appointed in the city of London by the common council and in the metropolis by the borough council.

The Rating Act, 37 \& 38 Vict. c. 54 (I874), abolished exemptions from the rating of woodlands, mines other than coal mines, and sporting rights severed from occupation. This Act extended the liability to rating under the Act of I601 of "saleable underwoods" "(I) To land used for a plantation or a wood or for the growth of saleable underwood, and not subject to any right of common; (2) To rights of fowling, of shooting, of taking or killing game or rabbits, and of fishing, when severed from the occupation of land; and (3) To mines of every kind not mentioned in the recited Act."

The Metropolis Management Act, 38 \& 39 Vict. c. 33 (i875), provided that properties not served by sewers, and thus not subject to the sewer's rate, should secure abatements upon the assessments on their properties. 
The Public Health Act, 38 \& 39 Vict. c. 55 (I875), was a comprehensive Act which provided for the making, assessment and collection of a general district rate to carry out the purposes of local urban government. It provided for the alteration of assessment districts for the purpose of general district rates by the urban authorities. The general district rate was to be under the supervision of the Ministry of Health.

The JuRISDiction IN Rating ACT, 40 \& 4I VICT. c. II (I877), authorized a judge to act notwithstanding that he was a ratepayer whose rates might be increased or diminished by the proceedings before him.

The Poor Rate Assessment and Collection ACT of I869 as amended by $45 \& 46$ VICT. c. 20 ( 1882 ), provided that an outgoing occupier was only liable to pay so much of the poor rate as should be proportionate to the time of his occupation within the period for which the rate was made, notwithstanding he might not be succeeded in his occupation by an incoming tenant.

The Municipal Corporation's Act, 45 \& 46 Vict. c. 50 (I882), gave power to municipal councils to make borough rates, provided for the collection of borough rates and the rating of owners instead of occupiers in certain cases, and exempted court sessions boroughs from county rate.

The Valuation (Metropolis) Amendaient Act, 47 Vict. c. 5 (I884), amended the Valuation (Metropolis) Act of $x 869$, by giving greater facilities to owners and lessors paying rates and taxes in place of occupiers.

The Local Government ACT, 5 I \& 52 VICT. c. 4I (I888), dealt, inter alia, with the establishment and powers of county councils. It provided for the abolishment of the general assessment sessions in the county of London set up in the Valuation (Metropolis) Act of 1869 , and that appeals were to go to quarter sessions as was the practice generally.

The Advertising Stations (Rating) Act, 52 \& 53 Vict. c. 27 (I889), amended the law with respect to rating places used for advertisements. The Act established a new principle in rating law in that it departed from the rule that the occupier was to be rated and substituted the person authorizing the exhibition of advertisements.

The Tithe Act, 54 Vict. c. 8 (I89r), made provision for the better recovery of the tithe rent charge.

The Public Libraries Act, 55 \& 56 Vict. c. 53 (I892), provided that the expenses of public libraries would be paid out of the borough rate, a separate rate or the general district rate arising out of the Public Health Acts.

The Local Government ACT, 56 \& 57 VICT. c. 73 (I894), removed the association of the ecclesiastical authorities with local government. The powers of the vestry were transferred to the parish council and rural district council, and it was provided that any municipal and county borough or urban district council could secure these powers by application to the Ministry of Health.

Merchants Seipping Act, 57 \& 58 Vict. c. 60 (I894), exempted all lighthouses, buoys, beacons, etc., and premises in connection therewith, from all rates.

The London Govern ment Act, 62 \& 63 Vict. c. I4 (I899), provided for the establishment and powers of metropolitan borough councils to take over powers lodged in vestrys and district boards.

THE FACTORY AND WORKSHOP ACT, I EDW. VII, c. 22 (IgOI), provided that yards, playgrounds and open spaces, schoolrooms, waiting-rooms and other rooms belonging to the factory or workshop, in which no machinery was used or manufacturing process carried on, should not be taken to be a part of the factory or workshop.

The Metropolis WATER Act, 2 EDW. VII, c. $4 \mathrm{I}$ (I902), provided for the creation of a water fund and water board to supply water to London. The vari- 
ous urban councils and municipal borough councils in and about London were to be represented on the board in proportion to the rateable value appearing in their valuation lists.

The City of London (Union of Parishes) Act, 7 Edw. VII, c. I40 (I907), provided that the assessment committee for the city of London Union should be appointed by the common council from among the members of that council, and that the Town Clerk should act as clerk to the committee. The assessment committee was to have possession and control of the valuation list, notices of objections, returns, etc.

The Bankruptcy Act, $4 \& 5$ Gro. V, c. 59 (I9I4), provided that rates should have a priority in the settling of bankrupts' estates.

The Statement of Rates Act, 9 \& io Geo. V, c. 3i (igig), provided that in all those cases of properties of low value wherein the landlord was liable for the payment of rates, the landlord must state upon every demand for rent or upon every receipt for rent, the amount of the payment made which would be applied to rates.

The InCRease of Rent and Mortgage Interest (Restriction) ACt, Io \& II Geo. V, c. I7 (I920), established rateable minima for compounding rates and the basis of rating new houses.

The Education Act, iI \& I2 Geo. V, c. 5I (I92I), exempted non-provided schools from rates. The main test of determining the question as to whether a school was non-provided was to ascertain if it received a government grant under the Education Act. Non-conformist day schools, Church of England and local Catholic schools are illustrations of non-provided schools. Schools "provided" by any public authority in accordance with the Education Acts were rateable for the same reason affecting any other public undertaking.

The Allotments Act, I2 \& I3 Geo. V, c. 5I (I922). Where a council had provided the land for the allotments, and had given notice to the rating authority requiring to be assessed as the occupiers, the council or society was to be rated instead of the occupier.

The Supreme Court of Judicature (Consolidation) Act, I5 \& i6 Geo. V, c. 49 (I925). A judge was not incapable of acting judicially in any proceeding by reason of the fact that he was one of several ratepayers liable in common to contribute to or be benefited by any rate which might be increased or diminished by that proceeding.

The Public Health Act, I 5 \& I6 Geo. V, c. 7I (I925), gave local authorities powers with respect to public parks and authorized a rate of Id. in the $E$ for any one year and a 2 d. rate where there was the consent of the Ministry of Health. 


\section{APPENDIX B}

The Local Government Act of I928, §68, I9 Gro. V, c. I7 (I929) adopts the following schedule from the Rating and Valuation Act of I925, Second Schedule, Ascertainment of Rateable Value, Part I, I5 \& I6 GEo. V, c. 90 (I925).

\section{"Deductions From Gross Value}

\section{(I)}

Class of Hereditaments

(I) Houses and buildings, without land, other than gardens, where the gross value does not exceed $£$ Io.

(2) Houses and buildings without land, other than gardens, where the gross value exceeds $t$ to but does not exceed $£ 20$.

(3) Houses and buildings without land, other than gardens, where the gross value exceeds $£ 20$ but does not exceed $£ 40$.

(4) Houses and buildings without land, other than gardens, where the gross value exceeds $£_{40}$ but does not exceed $t$ Ioo.

(5) Houses and buildings without land other than gardens where the gross value exceeds $E$ roo.

(6) Land (other than agricultural land) with buildings valued together therewith as one hereditament.

(7) Land (other than agricultural land) without buildings.
(2)

\section{Amount of Deduction}

An amount equal to 40 per cent. of the gross value.

$f_{4}$ or an amount equal to $33 \mathrm{I} / 3$ per cent. of the gross value, whichever is the greater.

f7 or an amount equal to 25 per cent. of the gross value, whichever is the greater.

Ero or an amount equal to 20 per cent. of the gross value, whichever is the greater.

E20 together with an amount equal to I6 $2 / 3$ per cent. of the amount by which the gross value exceeds $t$ roo.

An amount equal to to per cent. of the gross value.

An amount equal to 5 per cent. of the gross value.

"For the purposes of this part of this Schedule, the expression 'houses and buildings' does not include mills, manufactories or premises of a similar character used wholly or mainly for industrial purposes or hereditaments valued as part of any railway, dock, canal, gas, water, electricity, or other public utility undertaking." 